\title{
Lectotypification of three Linnaean names in Leucojum (Amaryllidaceae)
}

\author{
P. Pablo Ferrer-Gallego ${ }^{1} \&$ Manuel B. Crespo ${ }^{2}$ \\ 1 Servicio de Vida Silvestre, Centro para la Investigación y Experimentación Forestal (CIEF), VAERSA, Generalitat Valenciana, \\ Avda. Comarques del País Valencià 114, 46930 Quart de Poblet, Valencia, Spain \\ 2 Departamento de Ciencias Ambientales y Recursos Naturales (dCARN) \& Instituto de la Biodiversidad (CIBIO), Universidad de \\ Alicante, Apartado 99, 03080 Alicante, Spain \\ Author for correspondence: P. Pablo Ferrer-Gallego, flora.cief@gva.es
}

ORCID PPFG, http://orcid.org/0000-0001-7595-9302; MBC, http://orcid.org/0000-0002-3294-5637

DOI http://dx.doi.org/10.12705/654.12

\begin{abstract}
Lectotypes are selected for three Linnaean names in the genus Leucojum (Amaryllidaceae): L. aestivum, L. autumnale ( $\equiv$ Acis autumnalis), and L. vernum. The designation of the nomenclatural types is based on the consultation of Linnaeus's original material and the literature cited in the respective protologues. The names are lectotypified using specimens from Linnaean, Burser and Clifford herbaria respectively.
\end{abstract}

Keywords lectotype; Linnaean names; nomenclature; original material; typification

\section{口 INTRODUCTION}

Leucojum L. s.l. (Amaryllidaceae) is a genus of bulbous petaloid monocotyledons which comprises about 10-12 species distributed mainly in Europe and in the western and central Mediterranean area, from the Atlantic coast of Portugal and Morocco to the northern Balkans and Crimea (Stern, 1956; Lledó \& al., 2004). Most of them are cultivated for their ornamental value in the temperate areas worldwide.

A phylogenetic analysis of Leucojum s.l. by Lledó \& al. (2004), using plastid and largely non-coding nuclear ribosomal DNA sequences, supported the separation of Leucojum into two groups. On the one hand, the genus Leucojum L. s.str. was reduced to $L$. subg. Leucojum with only one representative species (L. vernum L.) plus $L$. subg. Aerosperma Stern with only one representative species (L. aestivum L., with two subspecies: L. a. subsp. aestivum and $L$. $a$. subsp. pulchellum (Salisb.) Briq.). On the other hand, the genus Acis Salisb. was revived to include L. subg. Acis (Salisb.) Baker (including Leucojum autumnale L. with 4 additional species) and L. subg. Ruminia (Parl.) Baker (with 3 species). An additional species, Acis ionica Bareka \& al. (=Leucojum ionicum Kit Tan \& al.) was later described to accommodate the Ionian populations previously ascribed to A. valentina (Pau) Lledó $\&$ al. The phylogenetic classification provided by Lledó \& al. (2004) is in full accordance with the distinction of two different groups in the genus proposed by Contandriopoulos (1962), based on morphological, ecological and cytological data. In the light of these results the genus Leucojum is broadly distributed in Europe and the northern part of the Mediterranean basin, whereas the genus Acis Salisb. occurs mostly in the W Mediterranean basin and NW Africa (Lledó \& al., 2004), with only one known species in the central Mediterranean area (Bareka \& al., 2006).

Linnaeus $(1753,1759)$ published three names in Leucojum s.l. at the rank of species: L. aestivum, L. autumnale (currently Acis autumnalis), and L. vernum. Leucojum aestivum subsp. aestivum occurs from Ireland through $\mathrm{C}$ and $\mathrm{S}$ Europe to the Caucasus, and is characterized by its flattened, broadly linear leaves $(0.6-1.3 \mathrm{~cm})$, fistulous scape up to $50-65 \mathrm{~cm}$ high, flowers numerous with white perianth segments bearing a green mark below the apex, and seeds large (5-7 mm), blackish, lacking appendages but with a spongy testa adapted to hydrochory. Acis autumnalis is distributed in SW Europe and NW Africa, and shows linear leaves $(0.05-0.2 \mathrm{~cm})$, canaliculate, solid scape up to $25 \mathrm{~cm}$ high, and white perianth segments lacking green or yellowish marks, though usually pinkish coloured mostly at the base, and seeds small $(1.5-2.5 \mathrm{~mm})$, blackish, lacking a strophiole. Leucojum vernum is found mainly in C Europe, and is morphologically close to L. aestivum, though usually smaller with scape up to $40 \mathrm{~cm}$, flowers mostly solitary with green or sometimes yellow marks below the apex of segments, and seeds showing a pale coloured outer coat and appendage.

These species have been the subject of many studies regarding their distribution, ecology, genetics and taxonomy (Stern, 1956; Damboldt \& Phitos, 1975; Bareka \& al., 2003, 2006; Lledó $\&$ al., 2004; Tan \& al., 2004). However, these Linnaean names still appear to be untypified (see Jarvis, 2007: 622-623). The purpose of the present paper is to contribute to stability of nomenclature by the lectotypification of these names according to the International Code of Nomenclature of algae, fungi, and plants (ICN, McNeill \& al., 2012). The designation of the corresponding types is based on the consultation of Linnaeus's original material and the literature cited in the respective protologues.

Received: 4 Jan 2016 | returned for (first) revision: 12 Feb 2016 | (last) revision received: 14 Feb 2016 | accepted: 14 Feb 2016 || publication date(s): online fast track, 15 Aug 2016; in print and online issues, 30 Aug 2016 || C International Association for Plant Taxonomy (IAPT) 2016 


\section{- TYPIFICATION OF THE NAMES}

\section{Leucojum aestivum}

Linnaeus's (1759: 975) protologue consists of a nomen specificum legitimum, "LEUCOJUM aestivum", associated with the letter "A", followed by a brief diagnosis "spatha multiflora, stylo clavato". Three years later, Linnaeus (1762: 414) published the same diagnosis and cited three synonyms, and also included the locus classicus "Habitat in Pannonia, Hetruria, Monspelii" and noted leaf differences between this species and both $L$. vernum ("Folia hujus lata ut in L. verno, ...") and L. autumnale L. (“... nec filiformia ut in L. autumnali"). The first synonym "Leucojum bulbosum majus s. multiflorum" was cited from Bauhin (1623: 55), the second "Leucojum bulbosum

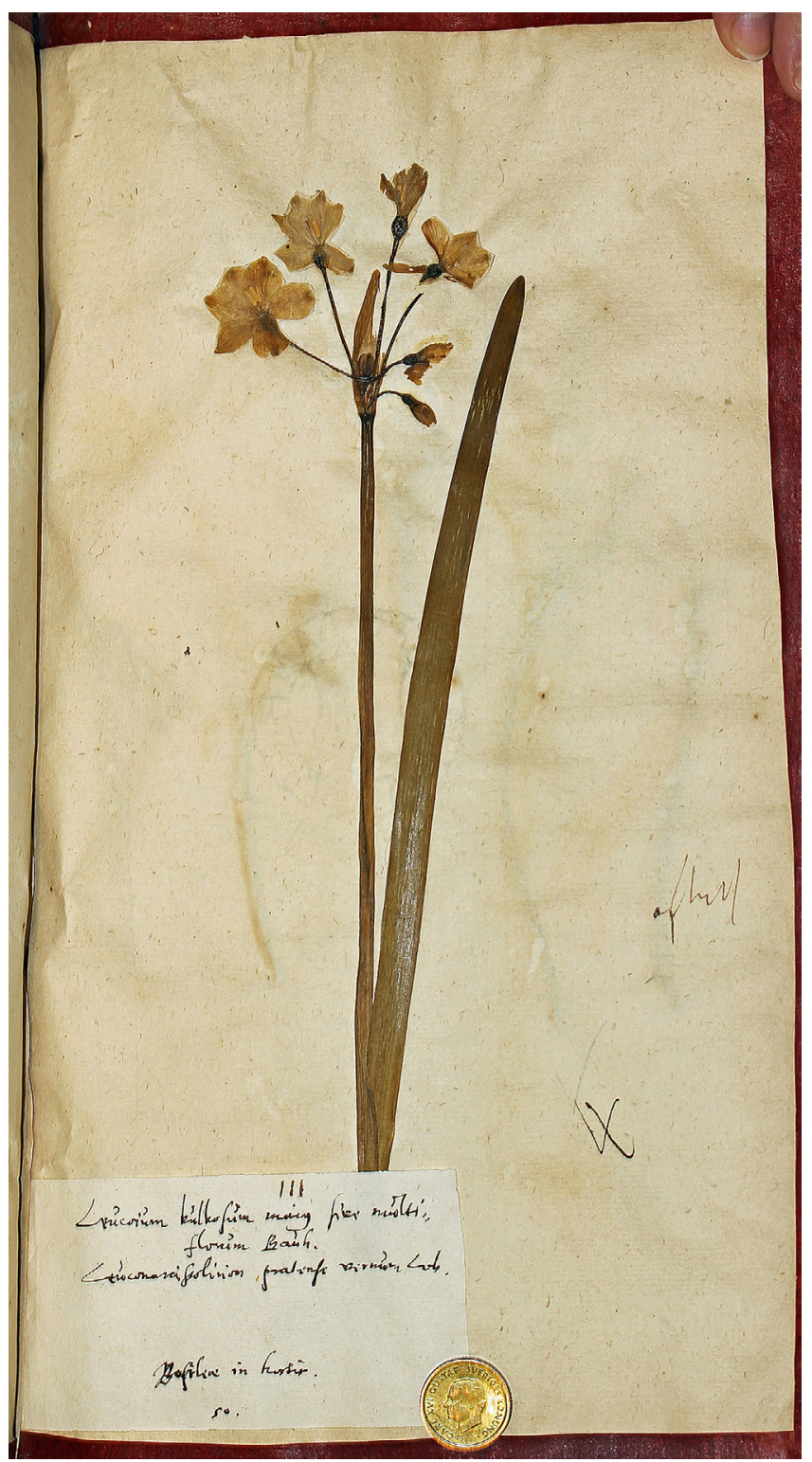

Fig. 1. Linnaeus's original material of Leucojum aestivum L. (Herb. Burser III: 50, UPS-BURSER). Photography by courtesy of Herbarium UPS; reproduced with permission. serotinum majus" from Clusius (1601: 170), and the third "Polyanthemum" from Reneaulme (1611: 99-100). Two illustrations were provided by these authors (Clusius, 1601: 170; Reneaulme, 1611: 100), but cannot be considered original material because they were not cited in Linnaeus's 1759 protologue (see Art. 9.3 of the $I C N)$.

Only one sheet is considered as original material by Jarvis (2007: 622), preserved at LINN, Herb. Linn No. 410.2 (image available at http://innean-online.org/3785/). However, in the Burser Herbarium at UPS, there is a herbarium sheet, Herb. Burser III: 50 (UPS-BURSER), with material that corresponds to Leucojum aestivum. The sheet is annotated "Leucojum bulbosum majus sive multiflorum Bauh." (see Stearn, 1957) and "Leuconarcissolirion pratense vernum Lob.", and bears a leaf (maximum width, $10.25 \mathrm{~mm}$ ), and an inflorescence with seven flowers (Fig. 1). Linnaeus's citation of the polynomial in Bauhin (1623: 55), "Leucojum bulbosum majus s. multiflorum", provides a link to the specimen Herb. Burser III: 50. Joachim Burser's herbarium was arranged and labelled according to Bauhin's Pinax (Jarvis, 2007), and this herbarium was in Uppsala where it was used by Linnaeus for the interpretation of the names that appeared in Bauhin's work. Therefore, this specimen is undoubtedly original material for the Linnaean name Leucojum aestivum. We have been unable to trace any other original material in any of the other Linnaean or Linnaean-linked herbaria that may have been used as part of the species description.

The herbarium sheet Herb. Linn. No. 410.2 (LINN) is annotated "Leucojum" and "A. aestivum" by Linnaeus, and bears a fragment of L. aestivum subsp. aestivum with an inflorescence and a leaf. This material represents the traditional concept (e.g., Willkomm, 1861) and current use of the name of this species (e.g., Webb, 1980; Aedo, 2013), and it is here designated as the lectotype of the name Leucojum aestivum.

Leucojum aestivum L. subsp. aestivum, Syst. Nat., ed. 10, 2: 975.1759 - Lectotype (designated here): Herb. Linn. No. 410.2 (LINN [digital image!]). — Image of lectotype available at http://linnean-online.org/3785/

\section{Leucojum autumnale}

Linnaeus's (1753: 289) protologue of Leucojum autumnale consists of a diagnosis "LEUCOJUM spatha multiflora, stylo filiformi. Loefl. [Löfling]" followed by three synonyms. The first, "Leucojum bulbosum autumnale", was cited from Bauhin (1623: 56), the second from Clusius (1601: 170), "Leucojum bulbosum autumnale tenuifolium", with the third synonym, "Leucojum bulbosum majus s. multiflorum", also from Bauhin (1623: 55). Linnaeus indicated the geographical provenance as "Habitat in Lusitania". Clusius (1601: 170) provided an excellent illustration that can be considered original material.

Among the original material cited by Jarvis (2007: 622), the sheet at LINN (Herb. Linn. No. 410.3; image available at http://innean-online.org/3786/) includes three fragments with only flowering scapes. The sheet is annotated " 2 autumnale" by Linnaeus, the original Linnaean species number from Species 
plantarum (Turland \& Jarvis 1997; Turland 2006; Jarvis 2007: 4146), and "Leucojum spatha multiflora, stylo filiformi / Leucojum bulbosum autumnale minus Clus.", "Lecta in Estremadura Hispania et Lusitania a D. Loefling" by Linnaeus on the reverse of the sheet (see Löfling, 1758).

In the Burser herbarium at UPS, there is a herbarium sheet, Herb. Burser III: 52 (UPS-BURSER), with material corresponding to Leucojum autumnale. The sheet is annotated "Leucojum bulbosum autumnale Bauh." (see Stearn, 1957) and "Leuconarcissolirion minimum autumnali Lob.", and contains only an inflorescence with three flowers in a poor state of preservation (Fig. 2). We have been unable to trace any further original material in any of the other Linnaean and Linnaeanlinked herbaria.

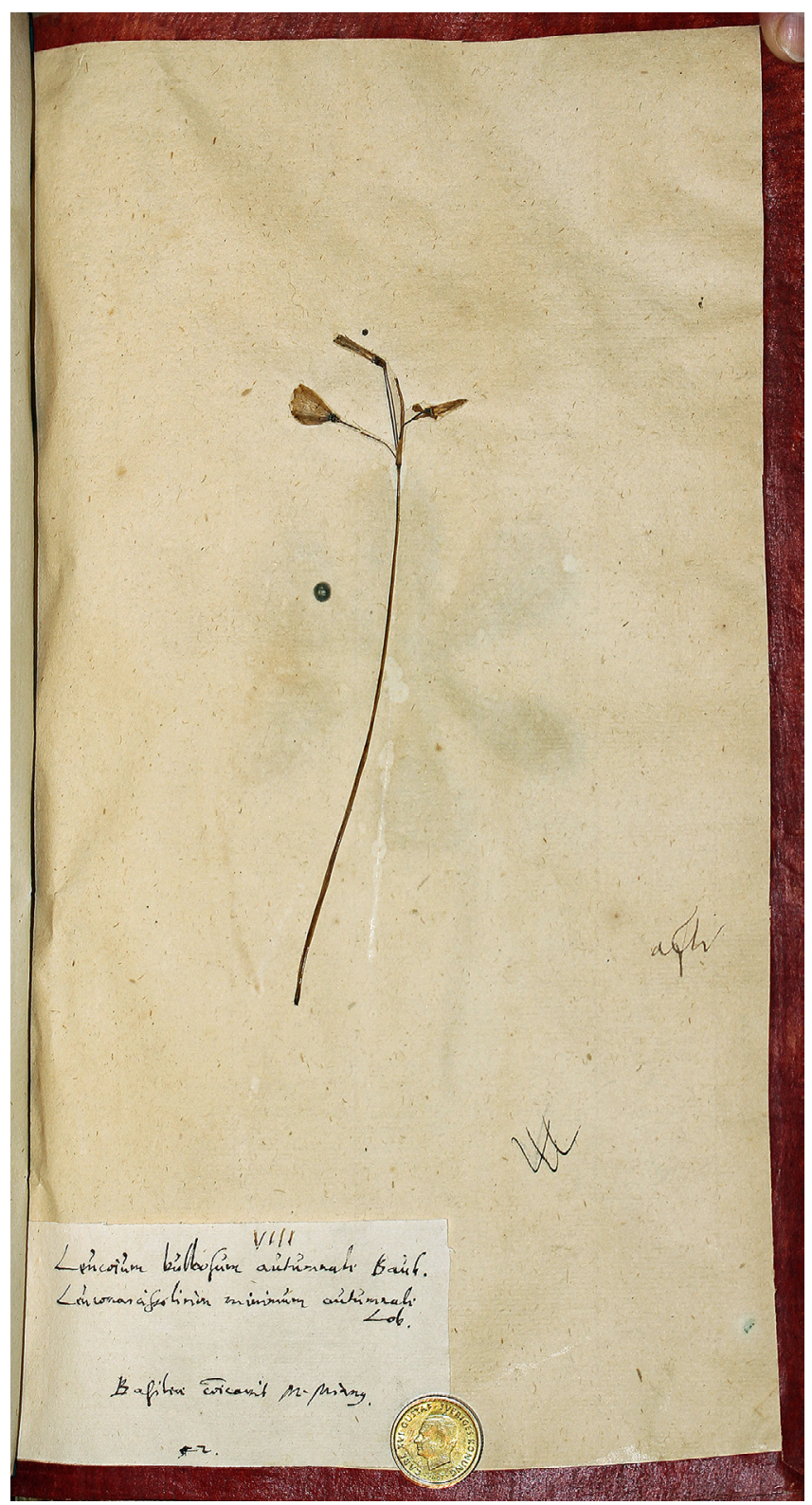

Fig. 2. Linnaeus's original material of Acis autumnalis (L.) Sweet (Herb. Burser III: 52, UPS-BURSER). Photography by courtesy of Herbarium UPS; reproduced with permission.
Because the specimen at LINN is a syntype (since it was cited by Linnaeus in the protologue as "Leucojum spatha multiflora, stylo filiformi. Loefl"), in lectotype designation it has precedence over the uncited specimens and cited illustrations (Art. 9.12 of $I C N)$. It is therefore the obligate lectotype and we accordingly designate it here as such. Fortunately, it is in a good state of preservation and, along with the specimen and the Clusius's illustration, this material agrees with the traditional and current usage of the names Leucojum autumnale and Acis autumnalis.

Leucojum autumnale L., Sp. Pl.: 289. $1753 \equiv$ Acis autumnalis (L.) Sweet, Brit. Fl. Gard. 3: t. 297. 1829 - Lectotype (designated here): Herb. Linn. No. 410.3 (LINN [digital image!]). - Image of lectotype available at http:// linnean-online.org/3786/

\section{Leucojum vernum}

Linnaeus's protologue (1753: 289) of Leucojum vernum consists of a diagnosis "LEUCOJUM spatha uniflora, stylo clavato" followed by three synonyms. The first synonym, "Leucojum", was cited from Linnaeus (1738: 135; 1748: 74) and Van Royen (1740: 35), the second from Bauhin (1623: 55), "Leucojum bulbosum vulgare", and the third from Reneaulme (1611: 99-100), "Oliganthemum". Linnaeus indicated the geographical provenance as "Habitat in Germaniae, Helvetiae, Italiae umbrosis pratis, ad rivulos". Reneaulme (1611: 100) provided an illustration that can be considered original material.

Among the original material cited by Jarvis (1991: 104-108; 2007: 623) four specimens are relevant to Leucojum vernum, one of which is at LINN (Herb. Linn. No. 410.1; image available at http://innean-online.org/3784/). The sheet is annotated "1 vernum" by Linnaeus. A second is preserved in the Burser Herbarium at UPS (Herb. Burser III: 49 [UPS-BURSER]) and linked to the synonym in Linnaeus (1753) "Leucojum bulbosum vulgare"; this sheet bears two complete plants fully identifiable as Leucojum vernum according to the Linnaean diagnosis (see Juel, 1936: 19; Stearn, 1957: 78), which were apparently collected in the south of France, "Monspelii sponte" (Fig. 3). In the Clifford Herbarium there is a herbarium sheet, Herb. Clifford: 135, Leucojum 1 (BM000558560), which can also be regarded as original material; the sheet contains two plants of L. vernum.

Finally, in the Museum of Natural History of the University of Florence there is a specimen, Herb. Linn. (FI), with Linnaeus's original material of Leucojum vernum, and probably a duplicate of the sheet preserved at LINN (Herb. Linn. No. 410.1) (see Savage, 1945). In this herbarium, a small, bound volume, presented to Filippo Parlatore during a visit to Sweden in 1851, now in Florence (see Parlatore, 1874), are nine herbarium sheets from the herbaria of Linnaeus, Linnaeus filius, Swartz, Thunberg, and Acharius (Jarvis, 1991: 103; 2007: 178). The sheet at FI bears two flowers and part of a single leaf, and is annotated "Leucojum vernum" and the number " 1 " in the handwriting of Linnaeus, and "von Linné seu. scripsit" (Fig. 4).

Among the mentioned elements (specimens from Clifford, Burser, and Linnaean [LINN and FI] herbaria, and illustration 


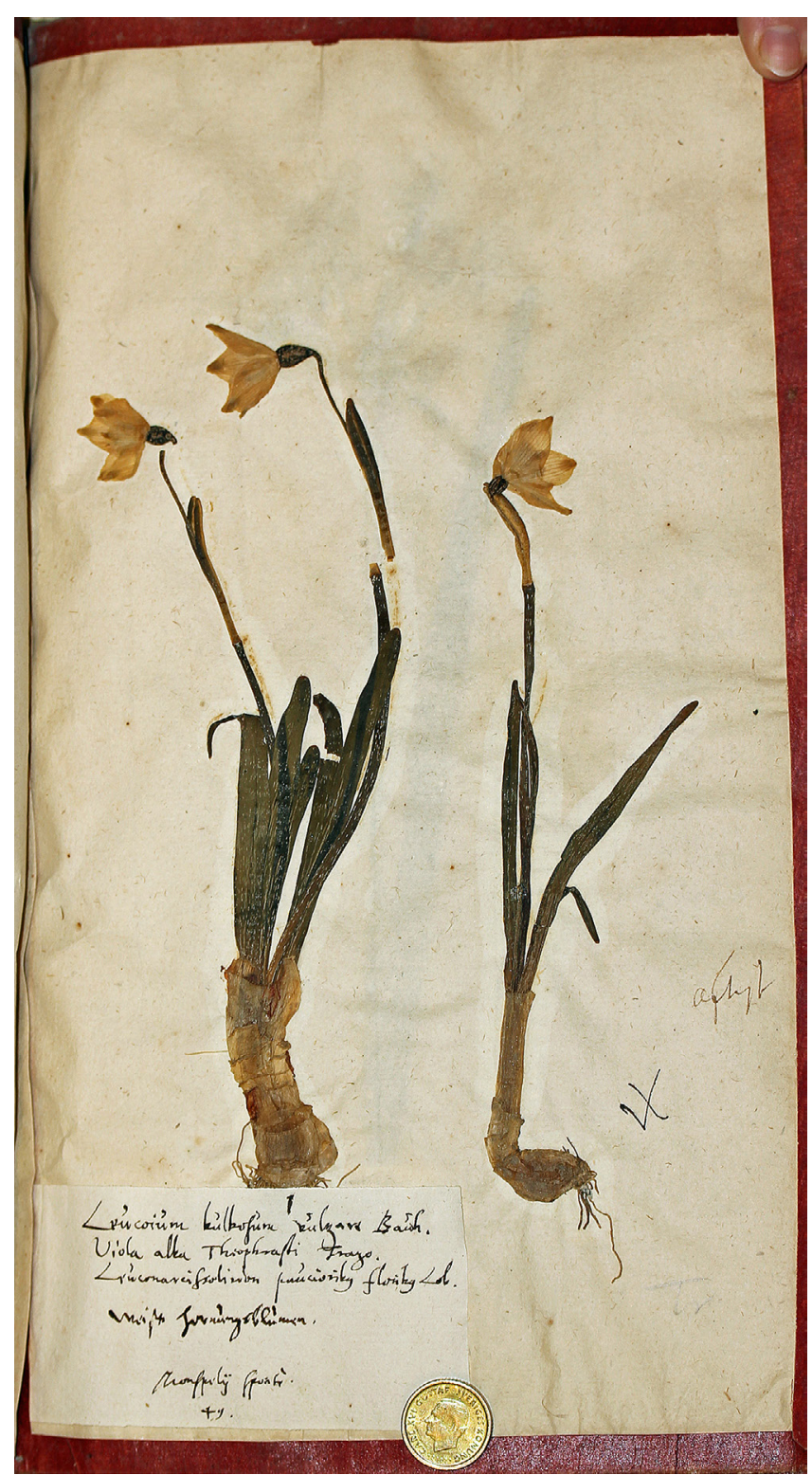

Fig. 3. Linnaeus's original material of Leucojum vernum L. (Herb. Burser III: 49, UPS-BURSER). Photography by courtesy of Herbarium UPS; reproduced with permission.

by Reneaulme), and despite the good state of conservation of the Burser specimen, the Clifford material at BM is the best choice for lectotype of the name Leucojum vernum, since it is the most complete and the best representative original material available.

Leucojum vernum L., Sp. Pl.: 289. 1753 - Lectotype (designated here): Herb. Clifford: 135, Leucojum 1 (BM barcode BM000558560 [digital image!]. - Image of lectotype available at http://www.nhm.ac.uk/resources/ research-curation/projects/clifford-herbarium/lgimages/ BM000558560.JPG

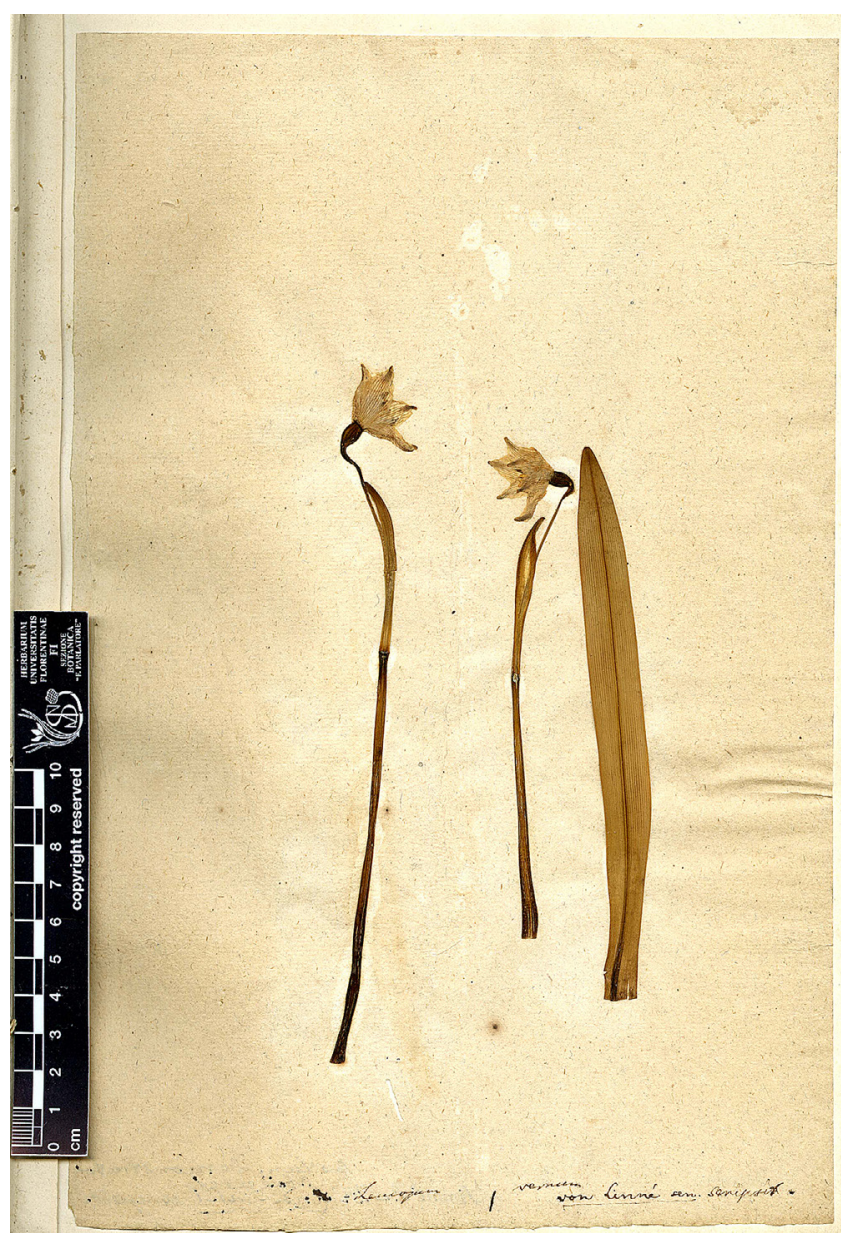

Fig. 4. Linnaeus's original material of Leucojum vernum L. (Herb. Linn. at FI). Photography by courtesy of Herbarium FI; reproduced with permission.

\section{ACKNOWLEDGEMENTS}

We thank the staff of the cited herbaria, especially Mats Hjertson (Museum of Evolution, Botany Section Uppsala University, Sweden), and Chiara Nepi and Egildo Luccioli (Natural History Museum, University of Florence, FI).

\section{- LITERATURE CITED}

Aedo, C. 2013. Leucojum L. Pp. 328-335 in: Rico, E., Crespo, M.B., Quintanar, A., Herrero, A. \& Aedo, C. (eds.), Flora iberica, vol. 20. Madrid: Real Jardín Botánico, CSIC.

Bareka, E.-P., Kamari, G. \& Phitos, D. 2003. Cytogeographic study of the genus Leucojum (Amaryllidacae) in Greece. Bocconea 16: $529-536$.

Bareka, E.-P., Kamari, G. \& Phitos, D. 2006. Acis ionica (Amaryllidaceae), a new species from the Ionian area (W Greece, S Albania). Willdenowia 36: 357-366. http://dx.doi.org/10.3372/wi.36.36131

Bauhin, C. 1623. Pinax theatri botanici. Basileae [Basel]: sumptibus \& typis Ludovici Regis. http://dx.doi.org/10.5962/bhl.title.712 
Clusius, C. 1601. Rariorum plantarum historia. Antverpiae [Antwerp]: ex officina Plantiniana, apud Ioannem Moretum. http://dx.doi.org/10.5962/bhl.title.724

Contandriopoulos, J. 1962. Recherches sur la flore endémique de la Corse et sur ses origines. Annales de la Faculté des Sciences de Marseille, sér. 2, 32. Marseille: Université d'Aix-Marseille.

Damboldt, J. \& Phitos, D. 1975. Die Karyosystematik der Gattung Leucojum L. (Amaryllidaceae) in Griechenland. Pl. Syst. Evol. 123: 119-131.

Jarvis, C. 1991. An undescribed Hortus Siccus of eighteenth century Swedish herbarium material in the Museo Botanico, Università di Firenze. Webbia 45: 103-115.

Jarvis, C. 2007. Order out of chaos: Linnaean plant names and their types. London: The Linnean Society of London and the Natural History Museum.

Juel, H. O. 1936. Joachim Burser's Hortus siccus. Symb. Bot. Upsal. 2(1): $1-187$.

Linnaeus, C. 1738 (“1737”). Hortus cliffortianus. Amstelaedami [Amsterdam]. http://dx.doi.org/10.5962/bhl.title.690

Linnaeus, C. 1748. Hortus upsaliensis. Stockholmiae: sumtu \& literis Laurentii Salvii. http://dx.doi.org/10.5962/bhl.title.692

Linnaeus, C. 1753. Species plantarum, vol. 1. Holmiae [Stockholm]: impensis Laurentii Salvii. http://dx.doi.org/10.5962/bhl.title.669

Linnaeus, C. 1759. Systema naturae, ed. 10, vol. 2. Holmiae [Stockholm]: impensis direct. Laurentii Salvi. http://dx.doi.org/10.5962/bhl.title.542

Linnaeus, C. 1762. Species plantarum, ed. 2, vol. 1. Holmiae [Stockholm]: impensis direct. Laurentii Salvii. http://dx.doi.org/10.5962/bhl.title.11179

Lledó, M.D., Davis, A.P., Crespo, M.B., Chase, M.W. \& Fay, M.F. 2004. Phylogenetic analysis of Leucojum and Galanthus (Amaryllidaceae) based on plastid matK and nuclear ribosomal spacer (ITS) DNA sequences and morphology. Pl. Syst. Evol. 246: 223-243.

Löefling, P. 1758. Iter hispanicum. Stockholm: tryckt på direct. Lars Salvii. http://bibdigital.rjb.csic.es/ing/Libro.php?Libro=66

McNeill, J., Barrie, F.R., Buck, W.R., Demoulin, V., Greuter, W., Hawksworth, D.L., Herendeen, P.S., Knapp, S., Marhold, K., Prado, J., Prud'homme van Reine, W.F., Smith, G.F., Wiersema, J.H. \& Turland, N.J. (eds.) 2012. International Code of Nomenclature for algae, fungi, and plants (Melbourne Code): Adopted by the Eighteenth International Botanical Congress
Melbourne, Australia, July 2011. Regnum Vegetabile 154. Königstein: Koeltz Scientific Books.

[online ed., http://www.iapt-taxon.org/nomen/main.php]

Parlatore, F. 1874. Les collections botaniques du Musée royal de physique et d'histoire naturelle de Florence au printemps de 1874. Florence: imprimeri successeurs Le Monnier. http://dx.doi.org/10.5962/bhl.title.41169

Reneaulme, P. 1611. Specimen historiae plantarum. Parisiis [Paris]: apud Hadrianum Beys. http://bibdigital.rjb.csic.es/ing/Libro.php?Libro=5524

Savage, S. 1945. A catalogue of the Linnaean herbarium. London: Linnean Society of London.

Stearn, W.T. 1957. An introduction to the Species plantarum and cognate botanical works of Carl Linnaeus. Pp. 1-157 in: Linnaeus, C., Species plantarum: A facsimile of the first edition, 1753, vol. 1 . London: Ray Society.

Stern, F.C. 1956. Snowdrops and snowflakes: A study of the genera Galanthus and Leucojum. London: The Royal Horticultural Society.

Tan, K., Mullaj, A., Sfikas, G. \& Strid, A. 2004. An autumn-flowering Leucojum (Amaryllidaceae) in South Albania and Western Greece. Fysi 107(Oct-Dec): 39-42.

Turland, N.J. 2006. Lectotypification of Campanula saxatilis, Phyteuma pinnatum and Verbascum arcturus, Linnaean names of three taxa endemic to Crete. Willdenowia 36: 303-309. http://dx.doi.org/10.3372/wi.36.36124

Turland, N.J. \& Jarvis, C.E. 1997. Typification of Linnaean specific and varietal names in the Leguminosae (Fabaceae). Taxon 46: 457-485. http://dx.doi.org/10.2307/1224388

Van Royen, A. 1740. Florae Leydensis prodromus. Lugduni Batavorum [Leiden]: apud Samuelem Luchtmans. http://dx.doi.org/10.5962/bhl.title.693

Webb, D.A. 1980. Leucojum L. Pp. 76-77 in: Tutin, T.G., Heywood, V.H.,Burges, N.A., Moore, D.M., Valentine, D.H., Walters, S.M. \& Webb, D.A. (eds.), Flora Europaea, vol. 5. Cambridge: Cambridge University Press.

Willkomm, H.M. 1861. Leucojum L. P. 148 in: Willkomm, H.M. \& Lange, J.M.C. (eds.), Prodromus florae hispanicae, vol. 1. Stuttgartiae [Stuttgart]: typis et sumtibus librariae E. Schweizerbart. http://dx.doi.org/10.5962/bhl.title.10112 